\title{
How the Sure Start Policy Is Implemented under the Labour Government in the UK: A Perspective of Implementation Network
}

\author{
Xiongwei Song ${ }^{1}$, Jingjing Zhang ${ }^{2} \&$ Hongyu Wang ${ }^{3}$ \\ ${ }^{1}$ Department of Political Science, Chinese Academy of Governance, Beijing, China \\ ${ }^{2}$ Faculty of Education, Beijing Normal University, Beijing, China \\ ${ }^{3}$ Department of International Relations, University of International Business and Economics, Beijing, China \\ Correspondence: Jinging Zhang, Faculty of Education, Beijing Normal University, Beijing, China. Tel: \\ 86-1-5880-0558. E-mail: jingjing.zhang@bnu.edu.cn
}

Received: November 2, 2013 Accepted: November 19, 2013 Online Published: April 29, 2014

doi:10.5539/par.v3n1p33 URL: http://dx.doi.org/10.5539/par.v3n1p33

\begin{abstract}
In 1997, the Labour Government came to power committed to reforming public service delivery, particularly towards the improvement of children's services. The paper focuses on the implementation process involved in rolling out its Sure Start policy in order to understand and analyse the dynamics in Labour's approach to delivery. In so-doing, it draws on implementation and policy network theories to offer an original analytical framework, 'the implementation network approach', to explain the implementation process of Sure Start policy in Sheffield and Manchester based on 32 interviews.
\end{abstract}

Keywords: labour, public service delivery, implementation network approach, sure start

\section{Introduction}

Under the previous Labour government, the issue of 'poverty and social exclusion' has become one of the most significant priorities in a number of policy areas. In the annual report of 'Opportunity for All, Tackling Poverty and Social Exclusion' in 1999, Labour outlines many facets of 'Poverty and Social Exclusion'. Social exclusion is a wide-ranging phenomenon representing systemic malaise, which cannot be solved just by the provision of income or jobs, but is a cross-cutting issue that needs to be dealt with by cross-departmental cooperation. It covers a number of policy areas, such as health, education, employment and so forth. The Sure Start programme, as one of the most important policy initiatives under the previous Labour government, has been considered as the key policy to tackle the problems of social exclusion and poverty of children and young people.

However, there are many critiques on the delivery process of Sure Start policy, and its impact on the improvements of children's lives. A report entitled 'Sure Start sets back the worst placed youngsters, study finds' from the Guardian in 2005, argues that:

The government's flagship Sure Start programme is setting back the behaviour and development of young children in the most alienated households, according to the first big national evaluation of the scheme. Though the £3bn programme is benefiting some poor families, the government commissioned study concluded that children of teenage mothers and unemployed or lone parents did worse in Sure Start areas than those in similarly deprived communities elsewhere (Guardian, 2005).

In addition, in a report on 15 February 2007, it argues that 'Norman Glass, Sure Start's founding director, complained after he had resigned; it went in the wrong direction. A significant proportion of the budget has been wasted on the provision of group day care - including expensive and unnecessary buildings' (The Times, 2007). This paper attempts to figure out what occurs in the process of implementation under the previous Labour government, as the issue of delivery has increasingly become the core theme of the Labour Administration's agenda.

The paper starts by analysing Labour's strategy on public service delivery setting out context for studying the implementation process of Sure Start policy; Then, the second part proposes a theoretical model - the Implementation Network - to offer a perspective on explaining the implementation process of Sure Start; Based on the proposed theoretical model, the paper then analyses the case studies of Sure Start policy in Manchester 
and Sheffield through the analytical lens of proposed theoretical model.

\section{Labour's Public Service Delivery}

The previous Labour government in the UK desperately engaged in the quest for public service improvement in the consecutive three terms of the Labour government since 1997. For the first term of the Blair Government, joined-up government was a central objective of public sector reform, covering both the making of policy and the delivery of services. The idea of 'joined-up government' as an emerging form of governance is closely associated with the 'hollowing-out' of the state and the increasing fragmentation and complexity of the public realm (Newman, 2001: 105).

By the end of its first term, The Labour government stated that delivery on its pledge to raise service standards is the single most important criterion for judging the success or failure of its second terms in office (Boyne, 2003). In examining the details of Labour's approach to public service reforms, a key point is that in a number of areas Labour was willing to accept a number of the reforms that had taken place in the previous eighteen years of Conservative government. Whitefield argues that 'the reality is that New Labour is creating market conditions in public services which include most of the structural components of markets' (Whitefield, 2006: 48). Partnership is a significant theme in Labour's approach to tackling complex policy issues. Non-state actors, such as voluntary sector bodies and private sector companies, still play important parts in the process of delivering public services, but they participate in a more coordinated way.

However, as Smith and Richards (2005) argue the policy capability of non-state actors is weakened through the strengthening of power from the centre. Even though Labour, rhetorically at least, stresses the roles of non-state actors and street-level bureaucrats in the partnership on improving public service delivery, it either implicitly or explicitly strengthens the controlling power from the centre. The claim here is that the relationship between the centre and non-state, street-level actors is asymmetric (See Figure 1).

\begin{tabular}{l}
\hline Political Control (Strengthening the centre's power) \\
Top-down approach \\
The institutionalization of Prime Minister's power, Special advisors and task forces, \\
Targets and Audit (PSA) \\
Administrative autonomy (stressing the importance of flexibility and freedom) \\
Bottom-up approach \\
Empowering to Non-State actors, and frontline public service deliverers
\end{tabular}

Figure 1. Labour's 'Mixed Approach' on reforming public services

Labour's approach, in particular, to public service delivery, has been based on wider devolution of powers. The government placed particular emphasis on developing new policy initiatives through integrated local actions. The Performance and Innovation Unit's report 'Reaching Out' (2000) listed thirty-two government-inspired series of zonal initiatives to bring local agencies together to develop holistic solutions to local problems, offering additional funding and greater flexibility in how funds were spent for successful bidders in order to foster local innovation. Their programme of reform has been framed in the context of devolving greater power to the frontlines and to non-state actors.

In developing greater choice of provider, the private and voluntary sectors can play a role. Contrary to myth, no one has ever suggested they are the answer. Or they should replace public services. But where use of them can improve public services, nothing should stand in the way of their use. In any event, round the world, the barriers between public, private and voluntary are coming down (Blair, 2001). 
In order to satisfy the demands and needs of customers and achieve customer-focused service, Labour enunciates four 'principles for Public Service Reform':

National Standards: means working with hospitals, schools, police forces and local government to agree tough targets and to see performance independently monitored so people can see how their local services compare.

Devolution: means Whitehall is serious about letting go and giving successful front-line professionals the freedom to deliver these standards.

Flexibility: means removing artificial bureaucratic barriers, which prevent staff from improving local services.

Choice: acknowledges that consumers of public services should increasingly be given the kind of options that they take for granted in other walks of life (Office of Public Service Reform 2002: 3).

Customer-focused public service reforms are based on these four principles, but for these to work effectively there must be a tight relationship between them. Standards and accountability are important, but they must be accompanied by the greater trust that comes from devolution, the greater rewards that come from more flexibility and the greater choice that the customer wants. 'The notions of choice and flexibility are explicit references made by the government in response to what it regards as an entrenched approach in Whitehall to delivery of public services based on a view that 'one size fits all' (Richards \& Smith, 2005). Governments can no longer claim to know everything and assume that something rigidly designed will fit the expectations of everyone in the nation.

For the government, diversity of customers' requirements and public service provision has become the new mantra. This is to be achieved through devolution and delegation to local providers, which can help tailor services to meet local needs. Labour freed up front-line professionals and street-level bureaucrats, who are best placed to understand the most appropriate means of delivery in order to meet the specific needs of their individual client groups (Office of Public Service Reform, 2002). One government on-line publication 'Leading from the Front Line', it illustrates clearly Labour's steps and intentions on freeing up street-level bureaucrats and gives several specific cases on granting teachers, police officers, GPs and Local officers more autonomy to cope with different situations (Cabinet Office, 2003a).

Rhetorically, Labour is committed to devolved and pluralistic forms of service delivery, delegation of management and the use of a range of public/private, local/national providers. However, the centre is seeking an alternative way to impose its control (top-down) on non-state actors and frontline bureaucrats. Labour created 'joined-up government' as a mechanism for increasing control by the centre, because it offers a way of ensuring that strategies developed in No.10 were not undermined by the conflicting goals of departments and different agencies or quangos. The Labour government also created a range of bodies such as the Social Exclusion Unit, task forces, the Delivery Unit, tsars and the Strategy Unit to overcome departmentalism and redress the failure of public service delivery.

It can be argued that under the Labour's government, the agenda is not ideologically driven, but output driven. The movement away from a concern with processes towards a stress on outputs means that non-state actors and frontline bureaucrats, such as agencies, voluntary organisations and quangos, are increasingly expected to deliver measurable improvements in their services by almost any means possible.

In order to strengthen the power of the core executive, Labour has taken the following measures:

1) Strengthening the Prime Minister's power. Blair expanded the size of the Policy Directorate, almost doubling numbers of personnel compared to the Major years (Smith and Ludlam, 2001). Crucially, the role of the Policy Directorate became one not so much of making policy but instead one charged with ensuring that departments were aware of the Blair agenda and were delivering policy in line with Number Ten's wishes. After 2001, Labour restructured the core executive and created the Prime Minister's Delivery Unit, which is used to ensure the delivery of the Prime Minister's top public service priority outcomes. Barber argued that: 'taken together with other Cabinet changes, and in the light of the development of the Office of Prime Minister over recent decades, it may well be that it marks a further stage in the evolution of British government from a Cabinet system to what is virtually a Presidential system' (Barber, 2007).

2) Increased the role of special advisers and task forces. The way that special advisers have been used can be illustrated by looking at both No.10 and the Treasury. In the Treasury, Gordon Brown oversaw an important change in the role of civil servants. Increasingly, policy is made in consultation with special advisers rather than the senior officials of the Treasury. In addition, Brown also had a collection of ad hoc advisers to undertake 'blue 
skies' thinking, their role being to keep the chancellor in touch with fresh ideas that are developing outside the corridors of the Treasury (Ludlam \& Smith, 2004). The Labour government also created an array of ad hoc bodies - task forces - with the intention of crossing departmental boundaries and providing a range of sources of advice. Task forces were intended to convey a spirit of urgency and commitment on the part of new administration intent upon action and delivery. 'They were designed to be emblems of Labour's desire to be seen to be implementing manifesto pledges briskly and in a spirit of trust' (Foley, 2000).

3) Utilizing audits and targets. There are a large number of regulatory bodies created by the last Conservative government, but again, rebranded by Labour. These include the Better Regulation Unit (later known as the Regulatory Impact Unit), the Better Regulation Task Force, the National Audit Office, the Audit Commission and the Public Sector Benchmarking Service. Growth in the use of targets and audit mechanisms reflects an attempt by central government to ensure it maintains control over those agencies or actors delivering services to the public (Hyndman \& Eden, 2002). However, one of the most important institutional forms of target-setting has been the establishment of Public Service Agreements (PSAs). The new spending regime has revitalized the role of Treasury in the domestic policy-making process, and the system has been perceived as consistent with the characterization of 'a 'strong' Treasury that actively intervenes in public activity' (James, 2004: 399). The PSA system was designed to bring all of central government under a system-wide performance regime to reduce fragmentation, and it was also intended to improve the co-ordination of priority setting where policy or delivery issues cut across departmental boundaries.

Labour's strategy for ameliorating public service has been to create a 'mixed approach' (See Figure 1). On the one hand, it stresses the importance of non-state actors and frontline bureaucrats in improving public service delivery and continues the legacy bequeathed by the Conservatives (1979-1997). On the other hand, it still believes that the centre should use a 'top-down' approach and it consistently imposes national standards on the service deliverers.

\section{The Implementation Network Approach}

There are two major approaches scholars have been using to interpret the implementation process, the 'top-down' (Pressman \& Wildavsky, 1984) and 'bottom-up' (Hjern, 1982; Hull, 1974) approaches. A 'top-down' approach may be inappropriate because the main actors shaping policy may be operating at the implementation level, so the policy is not dominated by central government departments (Cairney, 1999). Top-down approach prescribes the conditions to attain the success of policy implementation and reach the policies objective. In these cases, a 'bottom-up' approach recognises the complexity of the implementation process and argues that the: 'top-down model may not be appropriate used in situations where there is no dominant policy or agency, but rather a multitude of governmental directives and actors, none of them pre-eminent' (Sabatier, 1986: 30). Benson argues that the network of interests appear within a policy sector, which he defines in terms of: 'a cluster of complex of organisations connected to each other by resource dependencies and distinguished from other clusters or complexes by breaks in the structure of resource dependencies' (Parson, 2003: 484).

Under the previous Labour government, policies can be conceived as being implemented in pools of organisations, they may involve a multiplicity of organisations of various kinds - national and local, public, private and voluntary, business and labour, and so on - and implementation is often undertaken by a matrix or set of organisational pools not a single organisation (Parson, 2003: 484). Therefore, both top-down and bottom-up approaches have limitations in analysing the implementation process. Top-down approaches tend to overlook the complicated interactive process between different organisations, and merely focuses on central government's role on setting up a variety of conditions to establish the objectives of policies. As argued above, the great number of actors in the service delivery arena has increased the complexity of policy making under Labour, in part can be traced to the programme of marketisation and privatisation bequeathed by the previous Conservative regime.

Whitefield (2006) and Needham (2007) illustrated the increasing number of actors in delivering public services under the context of continuing markeitisation under Labour. Conversely, bottom-up approaches do account for the increase in complexity by taking account of the role of different organisations from both public and private sectors (Hjern, 1981). In addition, bottom-up approaches analyse the behaviours of street-level bureaucrats and their influence on the implementation process. However, the Labour government consistently strengthened central control through a variety of means, including PSA targets, institutionalising Prime Ministerial power, setting up task forces and using more special advisors. Nevertheless, bottom-up approaches have been criticised for their tendency to 'overemphasize the ability of the periphery to frustrate the centre (Hill \& Hupe, 2002: 64).

If then we recognise that the service delivery systems have become increasingly complex, disaggregated and 
indeterminate, policy network theory offers a complementary and useful approach to explaining implementation process and provides a framework to combine top-down and bottom-up approaches. As Richards argues, 'Many public goods are not delivered through a simple line bureaucracy but instead involve a series of complex interactions between numerous organisations and individuals' (Richards, 2005). This is particularly evident in an era of public service provision by contract, which relies on central authorities placing adequate incentives such as grants or market guarantees to secure participation. More actors are involved in the process of policy implementation than any time before. The following section primarily focuses on proposing a theoretical approach - the implementation network approach -- to analyse the implementation process (See Figure 2).

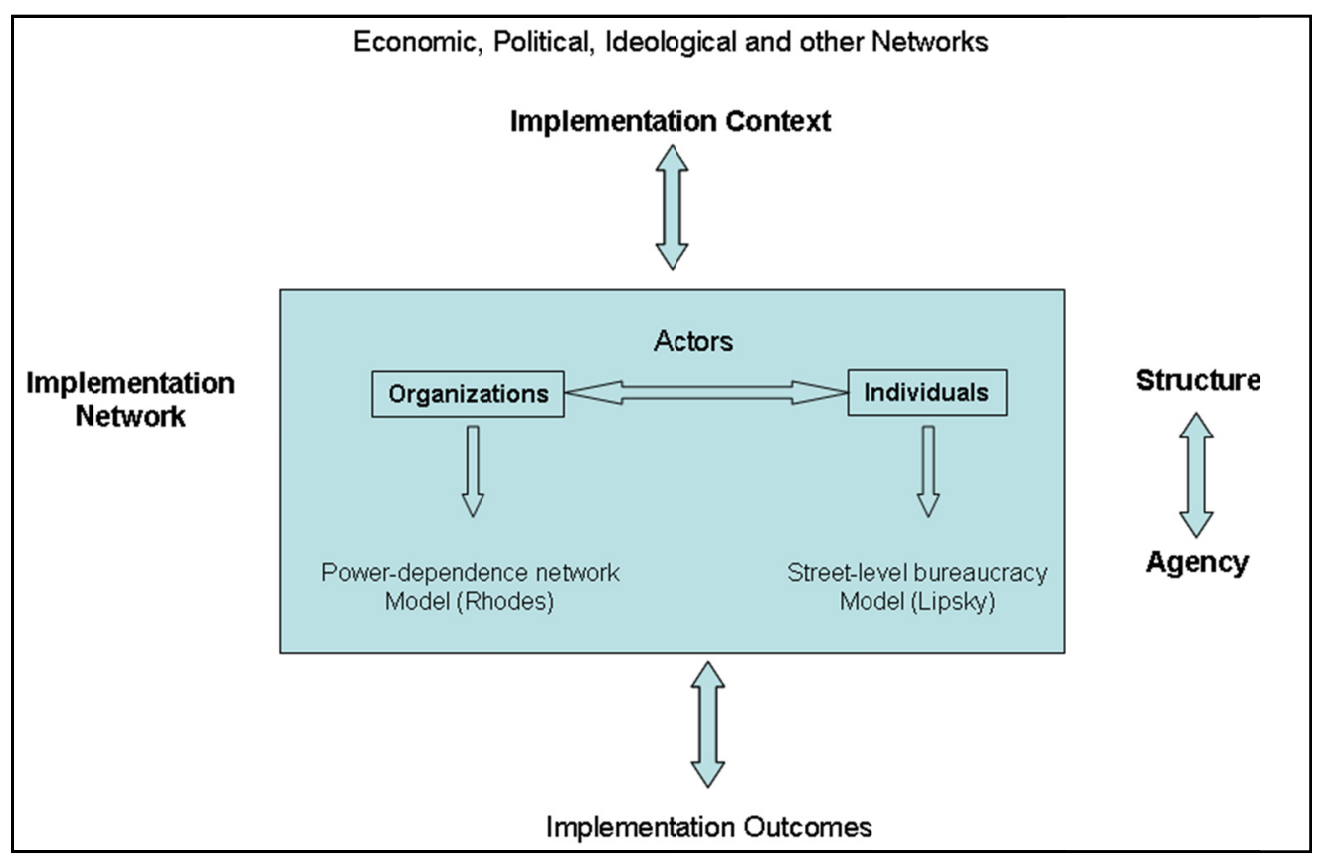

Figure 2. Song's implementation network approach

The implementation network approach is concerned with asking what is happening and why rather than simply: '...whether implementers comply with the prescribed procedures, timetables and restrictions' (Hill \& Hupe, 2002: 61). The implementation network approach goes beyond a typical top-down analysis, as it requires a recognition that a key determinant shaping policy in the implementation process stems are actors in the implementation network, rather than, for example, the central government ministries the dominance of. Here, while it is recognised that some of the bottom-up literature criticise the attempts to artificially impose a divisions of policy stages by top-down approaches, but as Sabatier and Jenkins-Smith (1993: 2) observe, that the: 'disaggregation of the complex and varied policy process into manageable segments' can be a useful research tool (Sabatier \& Jenkins-smith, 1993: 2). When applying the implementation network approach there is some recognition of the mutual effect of different policy stages and the implementers involved in the stages throughout the policy cycle. This separation of the policy stages allows for a category of the actors involved throughout the network and an analysis of both their status and role in the policy process.

The claim here then is that the implementation network approach importantly built on the existing literature offered by bottom-up approaches to recognise that the implementation process involves many key actors holding diffuse and competing goals who work within a context of an increasingly large and complex mix of government programmes that require participation from numerous layers and units of government and who are also affected by powerful factors beyond their control. Hajer (2003: 175) refers to this as the world of: "polycentric networks of governance'. In this context, a core theme of this research is to explore the discretion and autonomy of street-level bureaucrats and its impact on the implementation process under the Labour Government.

Here it is worth of outlining the five characteristics of the 'Implementation Network Approach' employed to explore this process: (1) The implementation network approach takes political, economic, ideological and other networks factors into consideration; (2) The implementation network approach embeds policy network theories 
into the framework. At the meso-level, Rhodes's policy network theory is employed to analyse the interactive process between different organizations in the implementation process. (3) The implementation network approach adopts a 'bottom up' approach to studying the implementation process; In the micro-level, Lipsky's 'street-level bureaucrats' model is used to analyse the behaviour of individuals at the street-level in the implementation process. Lipsky argues that 'street-level bureaucrats' have great discretion and autonomy in the implementation process both as decision-makers and implementers. (4) The implementation network approach explores the interactive relationship between structure and agency. They are structures that (Marsh and Smith, 2000) 'define the roles the actors play; shape the issues which are discussed and how they are dealt with; have distinct sets of rules; and contain organizational imperatives'. These structures also involve the institutions of beliefs, values, cultures and particular forms of behaviour. Marsh and Smith also argue that agents do make strategic calculations shaped by their interpretation of that structural context. (5) The implementation network approach recognises the importance of interactive relations between the network and outcome, arguing that not only do networks affect policy outcomes, but policy outcomes impact the shape of the policy network directly. Based on the recognition that policy outcomes also affect the shape of the policy network directly, as well as having an effect on the structural position of certain interests in civil society and the strategic learning of actors in the network.

\section{Research Methods}

Documentary analysis and interviewing are taken as the two most important methods of collecting the information and data on Sure Start policy. Bryman (2004) argues that there are five kinds of documentary sources, and they are: 'personal documents, official documents from the state, official documents from private sources, mass media outputs and virtual outputs (internet)' (Bryman, 2004: 380). Documentary sources pave the foundation for the interviewing stage. The documentary sources (See Table 1) have two primary roles. The first is to understand the background of Sure Start policy, its initiative stage, developing stage, and current progress, as well as exploring the related data on funding streams, targets and actors in Sure Start. The second is to identify relevant individuals to be interviewed and prepare for data collection in the subsequent interviewing stage.

Table 1. Documentary sources

\begin{tabular}{ll}
\hline Government official Websites & $\begin{array}{l}\text { DCSF, DWP, DoH, Sheffield City Council, Manchester City Council, PCT, } \\
\text { Jobcentre Plus, Sure Start Children's Centres, and other Private, Independent } \\
\text { and Voluntary actors involved in delivering Sure Start. }\end{array}$ \\
\hline $\begin{array}{l}\text { Governmental documentary } \\
\text { materials }\end{array}$ & $\begin{array}{l}\text { Civil Service Yearbook, Every Child Matters, Departmental Annual Reports, } \\
\text { Treasury Comprehensive Spending Review, Public Service Agreements, and } \\
\text { Sure Start related other documents }\end{array}$ \\
\hline $\begin{array}{l}\text { Existing literature and research } \\
\text { undertaken on Sure Start } \\
\text { programmes }\end{array}$ & $\begin{array}{l}\text { The National Evaluation of Sure Start, a series of researches on Sure Start } \\
\text { Local Programmes by Birkbeck College in UCL funded by Sure Start Unit, } \\
\text { and other relevant documents }\end{array}$ \\
\hline
\end{tabular}

In this research, semi-structured interviews are chosen as the most appropriate option for this particular research area, because it allows the interviewee space to express their thoughts and the interviewer the flexibility to adapt to new information during the interview, whilst maintaining enough structure to allow for comparisons to be made across interviews. Prior to each interview, a set of questionnaires was devised as a guide for the discussion, with different guides developed for the different types of actors, such as actors in the central government and actors at the local level. The purpose of the questions was to ensure that the interviews maintained focused on the key issues whilst providing flexibility to allow the respondents to bring in issues that they believed to be important to the policy area.

Specific interviewees are identified by analysing up-to-date primary literature from the target organisations (paper and electronic based), the Civil Service Yearbook and, in the later stages, information gathered in interviews with other actors (See Table 2). Interviewees are chosen from those involved in Sure Start policy from relevant departments and those initiating Sure Start policy. In addition, particularly at the local level, another important means of choosing interviewees is through the recommendations of other interviewees based on their local knowledge, since they know who relevant individuals are to contact on certain questions.

Interview materials is transcribed word by word from the tape recorder and checked several times to ensure 
accuracy. Secondly, the implementation network approach has been employed to explain service delivery of Sure Start. According to these explanatory variables, interview transcription is categorised and highlighted under different themes. For example, in order to reveal the importance of street-level bureaucrats involved in Sure Start policy and their impact on the implementation process, relevant interview material is highlighted, categorised and analysed comparatively between Sheffield and Manchester.

Table 2. Responses from interviewees in the fieldwork

\begin{tabular}{|c|c|c|c|c|}
\hline $\begin{array}{l}\text { Interview } \\
\text { Targets }\end{array}$ & $\begin{array}{l}\text { No. of Letters } \\
\text { sent out }\end{array}$ & $\begin{array}{c}\text { No. of Responses } \\
\text { with consent }\end{array}$ & $\begin{array}{l}\text { No. of Responses } \\
\text { with rejection }\end{array}$ & $\begin{array}{c}\text { No. of } \\
\text { non-responses }\end{array}$ \\
\hline DCSF & 15 & 1 & 0 & 14 \\
\hline DWP & 8 & 3 & 0 & 5 \\
\hline $\mathrm{DoH}$ & 3 & 0 & 0 & 0 \\
\hline Treasury & 2 & 0 & 0 & 0 \\
\hline $\begin{array}{l}\text { Social Exclusion and } \\
\text { Task Force }\end{array}$ & 1 & 1 & 0 & 0 \\
\hline No 10 & 2 & 0 & 0 & 0 \\
\hline Manchester & 1 & 1 & 0 & 0 \\
\hline \multicolumn{5}{|l|}{ City Council } \\
\hline $\begin{array}{l}\text { Sure Start Children's } \\
\text { Centres in Manchester }\end{array}$ & 20 & 10 & 6 & 4 \\
\hline Sheffield City Council & 2 & 2 & 0 & 0 \\
\hline $\begin{array}{l}\text { Sure Start Children's } \\
\text { Centres in Sheffield }\end{array}$ & 18 & 9 & 2 & 7 \\
\hline PCTs & 2 & 1 & 0 & 0 \\
\hline Jobcentre Plus & 3 & 0 & 0 & 0 \\
\hline $\mathrm{NCH}$ & 1 & 0 & 0 & 0 \\
\hline MCDT & 1 & 0 & 0 & 0 \\
\hline Barnardo's & 2 & 0 & 0 & 0 \\
\hline The BigLife Company & 2 & 0 & 0 & 0 \\
\hline $\begin{array}{l}\text { Employees in Sure } \\
\text { Start Children's } \\
\text { Centres }\end{array}$ & & 3 & & \\
\hline Total Number & 83 & 31 & 8 & 30 \\
\hline
\end{tabular}

In addition, as noted above, the triangulation method is used to interpret the collected data. Interview data was analysed against the statements of the governmental official documents. Through the analysis and interpretation of the interview data, it reveals to what extent Labour has actually devolved power and autonomy to frontline staff as stated in Labour's official documents. In addition, PSAs are a key tool for the Treasury to intervene with the actors involved in Sure Start policy. By analysing interview data against PSA targets, this work aims to reveal how different actors both at the centre and local level view the roles of the PSA.

\section{Implementing Sure Start in Practice}

Labour's objective is to guarantee that, in the next two decades no child will live in poverty and all children will have opportunities to realise their full potential (Office of Deputy Prime Minister, September, 2003). Sure Start is a programme designed by Labour to deliver on these stated aims, which brings together early education, childcare, health and family support. It concentrates on promoting the physical, intellectual, social and emotional development of young children to enable them to thrive when they go to school. However, in order to reach the objectives of Sure Start, Labour has been acutely aware of the importance of effective delivery. Since 2004, 
Children's Centres are moving from a range of previous local initiatives, such as local programmes, to a mainstream national service, which builds on successes of Sure Start local programmes, early excellence centres and neighbourhood nurseries and mainstreams the lessons learned to extend the benefits to all families.

This article prompts the questions that how the Sure Start are implemented since the establishment of Children's Centres through the implementation network approach based on the 32 interviews in both Sheffield and Manchester. In both Sheffield and Manchester, there are similarities and varieties in the implementation process of Sure Start policy. In Sheffield, EYECS (Early Years Education and Childcare Services) takes the leading role of developing Sure Start policy instead of relying on other accountable bodies, such as NCH (National Children's Home) and MCDT (Manor and Castle Development Trust); In Manchester, the Sure Start unit has the strategic role of rolling out Sure Start programmes. In terms of contextual factors, a joined-approach as a new way of delivering Sure Start policy has been applied in both cities. However, funding allocation for Sure Start is different in both cities. In terms of structural differences, different organisations are involved in the implementation process, for example, in both Sheffield and Manchester, there are different private, voluntary and independent organisations participating in the delivery process of Sure Start. In addition, there are variations in terms of autonomy and discretion of street-level bureaucrats in both cities.

This part attempts to understand the implementation process of Sure Start in Sheffield and Manchester through answering the following the questions: How has Labour's mixed approach on public service delivery influenced the implementation process of Sure Start policy? How do the different organisations involved in implementing Sure Start work together? What is the role of Sure Start policy deliverers, and to what extent do their autonomy and discretion influence the implementation process?

\section{1 'Joined-up Government and Mixed Approach'on Delivering Sure Start}

'Joining up' as a new governing mode has had a clear impact on the implementation process of Sure Start policy, since it focuses on cross-cutting delivery, shared goals, institutional restructuring and collaboration arrangements In the first place, the traditional political approach of a singular organisation delivering public services has been transformed to multi-agency working and partnership arrangements. At the central level, the objective of Sure Start is not merely the responsibility of a single department or organisation but needs collaboration from other departments. One of the senior officials from DCSF commented that 'DoH and DWP have dual responsibilities to help children to reach their own full potential, especially with the help of getting parents back to employment and copying with the health issues of children' (personal interview).

At the local level both in Sheffield and Manchester, Sure Start Children's Centres are multi-purpose centres that bring together childcare, early education, health and family support services. They are designed for use by families, parents and carers of children under five and may be based in schools, health centres, community centres or in their own building. Public, private and voluntary organisations work together, such as $\mathrm{NCH}$ and MCDT in Sheffield, or Barnado's and the Big Life company in Manchester, to provide a wide range of services from childcare to health visiting, employment advice, parenting advice and toy libraries for all young families, but with a particular emphasis on improving the life chances of the most disadvantaged children.

The way of delivering Sure Start services has been transformed under Labour's strategy of 'joined-up' governance, but it also brings new problems to the implementation process of Sure Start. Collaboration between departments is challenging, as one of the interviewees from the Social Exclusion Task Force in Whitehall commented. 'It is not just joined-up across the department, but within the department, with early years, there are some early year settings in private sector, some in voluntary. Getting a coherent approach across schools, private, non-profit organisations, nursery and voluntary organisations in terms of the way of their running things is very difficult. Even within the department, the complexity of the stakeholders in Sure Start policy was very difficult' (personal interview).

Departmental views on how to run Sure Start are different. One of the officials from the Social Exclusion Task Force commented:

There was a tension in the extent to which we dictated what should happen from the centre and the extent to which parents themselves have a role to play in running Sure Start programme and Children's Centres. We started from a strong view about local community control, and increasingly that cannot work it out, into local control you must do this, local control you must do that. There is really a tension which is not just joined-up horizontally across government but joined-up vertically in terms of what we wanted and what local community they want, what government should do. Those are real barriers we have.

At the local level, the Treasury has respective budgets for children, local authorities and PCTs, and they have to 
join these up locally. One of the senior officials from the central government commented that 'there would be a lot easier if they could be joined-up nationally' (personal interview). In terms of children and young people funding streams, there are Sure Start Revenue Funds, the Children's Fund, the Connexions Fund, Children Service Grants and Teenage Pregnancy Funding. Sure Start revenue funds support the delivery of district commissioning arrangements where resources will be allocated to support the core offer and ensure that outcome-focused delivery to the under fives population is a priority. In Sheffield and Manchester, it concludes that there is a similarity in both local authorities, which receive a wide range of different and complicated funding streams from different central departments in the Whitehall (personal interview).

Richards and Smith argue on the one hand that Labour emphasise the significance of frontline staff in delivering public services through the devolution of more power to street-level bureaucrats; on the other hand, they argue that the Labour government also attempts to control the behaviour of lower-level workers in order to increase the power of the central government through a variety of means, such as targets (Richards \& Smith, 2005). First and foremost, some senior officials in the central government describe the way the Labour government delivers public services are based on asymmetric relations between the centre and non-state actors and frontline staff. One of the officials from the Social Exclusion Task Force observed:

The managers who had huge amount of independence would be unhappy, because they think you are taking away the community control, and in some sense, that is true. We are moving from neighbourhood to town hall, moving from Whitehall to town hall. So from central who are devolving control from neighbourhood, we are absorbing control, there was a lot of dissatisfactions. I think, if you want to embed it as a part of the system, then you need to give it to local authority. There is a danger of losing parents participation and dangers of losing a sense of community. I think you have to guard against the risk, that is just my sense.

In addition, more than two thirds of managers interviewed in Sure Start Children's Centres in both Sheffield and Manchester thought that they are considerably constrained by limited budgets and resources, even though they feel they have some autonomy. Furthermore, they argued that their autonomy is also hindered by the framework set by local authorities and the central government. One of the managers from Sure Start Children's Centres in Manchester commented:

Obviously the framework set by local authority, central government, we have discretion that how you act at local level, but you are very constrained by the fact that you have very limited resources, is the key factor, so your ability to do anything is limited, because you don't have any resources to spend.

One of the managers from Sure Start Children's Centres in Sheffield also commented that 'our money is from local authority and the central government. Though we are allowed to make our own decisions on dealing with daily issues in the community, we are very much restrained by local authority and the central government as they hold the most resources we need' (personal interview).

\section{2 'Policy Community' and 'Issue Network' in the Sure Start}

Based on the interview, this section identifies that DCSF, DWP (Jobcentre Plus), DoH (PCT), No10, the Treasury and local authorities (EYECS in Sheffield and Sure Start Unit in Manchester) constitute the policy communities in Sure Start, and argues that DCSF, DWP, DoH, No10 and the Treasury make up a decision-making body that is not directly involved in the implementation process of Sure Start; and local authorities, PCTs and Jobcentre Plus constitute the implementation element of the policy community. They maintain a stable relationship within the communities in terms of delivering Sure Start.

Actors in the Sure Start policy community are firstly resources-dependent and rely on each other to reach their own targets; secondly, they need to establish an institutional mechanism to make sure their own interests are reflected in the policy community. No. 10, the Treasury, DCSF, DoH, and DWP are the actors in the policy community that negotiate resource exchanges in the decision-making process, which in turn have an impact on the implementation process of Sure Start. Jobcentre Plus, local authorities and PCTs are actors in the community that implement the decisions made in the community representing the interests of policy community (See Figure $3)$.

Ideologically they share the vision of ending child poverty by the end of 2020. More importantly, the vision is documented in governmental papers under Labour's overall strategies on reforming social welfare policy (First Annual Report, 1999). The Government also strongly believe in the efficacy of partnerships between public sectors and non-public sectors, such as private actors. Institutionally, they form a tight and closed structure dominating the decision-making and implementation process on Sure Start policy. Richards and Hay propose 'a 
strategic approach to networking within the core executive', and argue that 'networking is understood as a practice - an accomplishment on the part of strategic actors (or the organizations they nominally represent) - which takes place within a strategic (and strategically selective) context which is itself constantly evolving through the consequences (both intended and unintended) of strategic action' (Richards \& Hay, 2000: 14). Actors in the Sure Start policy community use strategic actions, such as agreed ideological consensus and established institutions, to exclude other groups and issues from the policy agenda. However, under the broad consensus among actors in the Sure Start policy community, this section reveals the disaggregated ideologies and institutional divisions inside the policy community in the decision-making process, which to a large extent affects the implementation process of Sure Start.

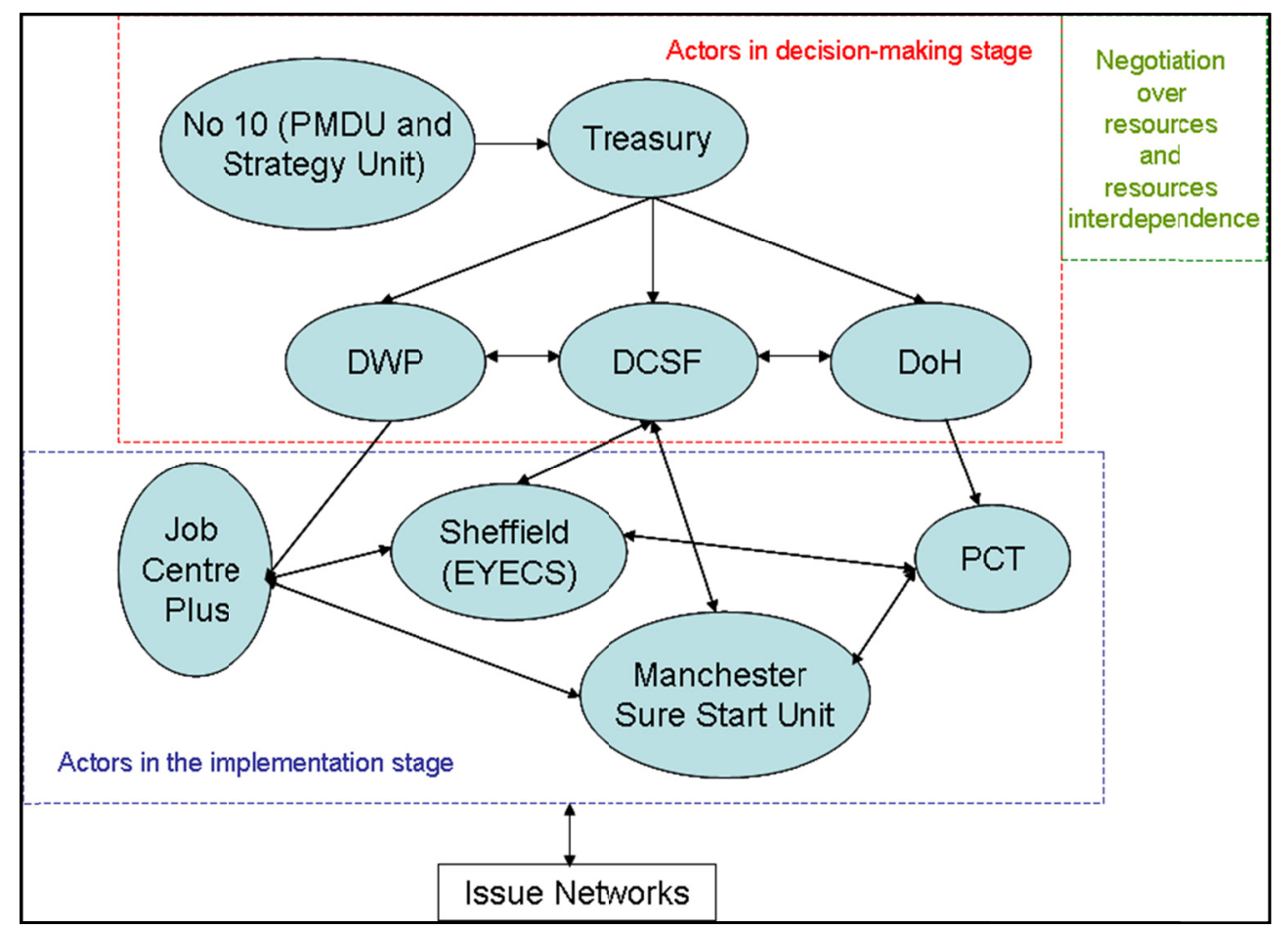

Figure 3. Actors in policy communities in Sheffield and Manchester

\subsubsection{Disaggregated Ideologies in the Community}

While Marsh and Rhodes' description of policy community identifies a set of dominant beliefs shared by members in the policy community as argued above, it fails to further explore the internal ideological divisions among actors in the community at the decision-making stage, which to a large extent acts as an influence on the implementation process of Sure Start. There are two types of decisions made in the community; the first decision type is that actors' fundamentally shared beliefs and ideologies in the community are being challenged as argued above; the second is that actors make decisions in favour of themselves as they encounter goal conflicts, cultural differences and resources constraints in the community. For example, in the decision-making circle in the policy community in Sure Start, DCSF is more concerned with the outcome for children and DWP is more concerned with employment. DoH focuses more on children's health and teenage pregnancy. Their views diverge significantly on how to solve these problems. DCSF attempts to achieve the shared policy aims through improving the outcome of children. In contrast, DWP aims to attain the shared aim by increasing parental employment (personal interview). DoH concentrates on improving children's health to alleviate children's poverty. One of the officials from the DCSF illustrated:

Even though they have the same priority, but different emphasis and different wording. DCSF talk about more on outcome for young children, childcare, nursery school, and DWP talk about employment, but it is the same way.

Lowndes and Skelcher argue that 'resource dependency issues have been an important motivator in the development of partnerships by UK public service agencies' (Lowndes \& Skelcher, 1998: 2). In this policy 
community, the Treasury attempts to control public spending and restrain it within a certain scope. Hence DCSF, DWP and DoH have to negotiate with the Treasury to bid for their respective funding to deliver the services. One of the senior officials from the DWP commented:

There is a natural conflict between us. We want money to defend the service, and the Treasury who wants to control public spending, so we have both negotiations on Comprehensive Spending Review.

DCSF is in the centre of the Sure Start policy and holds the key interest in delivering Sure Start Children's Centres, and it has the responsibility to communicate with other departments to encourage them to recognize that Sure Start Children's Centres can help them to reach their targets set by the Treasury. DCSF sees Sure Start Children's Centres as the best means to achieve the shared aim with other actors involved in Sure Start policy community. One of the senior officials from DCSF commented:

We have a lot of meeting with DWP, the same with health. We try to let DWP use their communication with Jobcentre Plus managers to understand Children Centre can help them to reach their targets at the National level. Employment service is key to Children Centre service, particularly around helping young mothers getting back to work, either education training.

Even though DWP's departmental PSA objective is to end child poverty by 2020, the main aim for DWP is to meet the needs of lone parents, and ensure that Sure Start benefits low-income families, which is also reflected at the local Jobcentre Plus. DWP considers getting more parents back to work as one of the best means to end child poverty by 2020. One of the senior officials from DWP illustrated:

I mean, the challenge to ensure to meet the needs of lone parents families for DWP, you know both for wide social reasons. DWP is to make sure that Sure Start is tuned to the low-income families. Both for wider social reasons, we care about poverty; lone parents families, especially to get the lone parents to work.

Norman Glass, a creator of the government's much vaunted early years childcare programme, in 2005 accused the DoH of showing no interest in Sure Start since it was founded (Communitycare.co.uk, 2005). However, DoH, as one of the stakeholders in Sure Start, does pursue its own objective within the broad ideological framework. It considers the Sure Start Children's Centre as one of the instrumental tools to reach its targets. At the same time, $\mathrm{DoH}$ is not willing to invest as many resources as they can, which can have a direct impact on the role of the PCT as implementer in the policy community. One of the senior officials from DCSF illustrated:

Culture is one of the main challenges when working with DoH, people working different ways, trying to get them to work together and respect each other, understand what other does, is quite challenging. Again, the Children Centre are modelling expertise and help health visitors professionally. They have more satisfaction from it

\subsubsection{Institutional Divisions in the Community}

The internal institutional structure inside the policy community still has its divisions and has a slow development process regarding partnerships in the implementation circle of the community, especially with actors such as Primary Care Trust and Jobcentre Plus.

1) DCSF(LA) and DWP (Jobcentre Plus)

Sure Start-related services in local authorities in both cities (EYECS in Sheffield and Sure Start Unit in Manchester) are line managed, supervised and overseen by DCSF. In Sheffield, based on the interview materials, the working relation between DCSF and the local authority is comparatively better than Manchester. EYECS has been chosen by DCSF as one of the leading authorities to develop guidance around the childcare strategy and is in a position to influence the way in which DCSF develops Sure Start policy. One of the officials from the local authority in Sheffield commented 'Our relation with DCSF is very good. They (DCSF) kind of oversee, they support us in the delivery of all the Children Centres and we report back to them about' (Personal interview)

In Manchester, officials in the Sure Start Unit also recognise the leading role of DCSF and the Unit is monitored as well by DCSF. However, officials in the Sure Start Unit are more concerned with the problems with DCSF and argue that 'the main issue for us is the time schedule is quite constrained, in terms of how to deliver a programme in two years. That is fairly tight in terms of planning a building, get it open and ready (Personal interview).

However, DCSF and local authorities (EYECS and Sure Start unit) are not the only players in the community, with DWP and Jobcentre Plus, together with DoH and PCT, also having important roles in the process of decision-making and implementation in Sure Start policy. In institutional terms, there is a mechanism to ensure 
the involvement of DWP and that its policy concerns are being reflected in the community. At the local level, Jobcentre Plus is line-managed by DWP, which largely determines the extent to which Jobcentre Plus provides services concerning the employment of families with children under five, and it jointly works with local authorities in a concerted way in the implementation process of Sure Start.

In Sheffield, one of the officials from the local authority argued that Jobcentre Plus is minor element of the work of DWP and there is a lack of the level of commitment and focus from Jobcentre Plus (personal interview). Jobcentre Plus is not seen by other members within the partnerships as absolutely central to the main purposes and roles of the Centres, and rarely seen as vital or crucial. As a result, Jobcentre Plus cannot reasonably expect to play a central or pivotal role in these partnerships (Dench, Aston, James, \& Foster, 2008: 59). One of the senior officials from the Local Authority in Sheffield commented that

I think it is just a lack of understanding. It might have something to do with the high turnover of their managers in Jobcentre Plus. And I think there is reluctance in some cases for workers to come out of their offices. I think there is something to do with the set of their organisations.

In Manchester, the Sure Start unit encounters resources issues in its partnership with Jobcentre Plus. Jobcentre Plus faces financial and human resources cuts due to the decisions made by DWP in the policy community. In Manchester, staff in Jobcentre Plus have been cut across the county, partnership managers especially, which decreases Jobcentre Plus' partnership capacity with the Sure Start unit. For example, one of the senior officials from Manchester Local Authority commented:

Partnership managers are part of Jobcentre Plus, but have to cover a big patch. I think, it feels like the capacity issue now.

In the implementation process, as DWP encounters the constraints of resources, particularly in Jobcentre Plus, it tends to restrict the services offered to local authorities. From interviews, both senior officials in Sheffield and Manchester indicated that there is a lack of strong cooperation with Jobcentre Plus, and the only service occurring in Sure Start Children's Centres is information provision to families with children under five and nothing else in most centres. It is reported by a number of Children's Centres staff that Jobcentre Plus is often viewed negatively and with distrust by both professionals and users, and still perceived by many as an agency that is largely interested in reducing the number of benefits claimants and individuals' own benefit entitlements by pushing people into work (Dench, Aston, James, \& Foster, 2008: 72). One of the senior officials from the Sheffield local authority commented:

In fact, they kind of think that Children's Centres should do everything, they don't want to do their own work, but they want all their boxes ticking. So they want to have their targets reached, but they don't want to do anything about it, so they want Children's Centres to reach targets for them.

2) DCSF (LA) and DoH (Prime Care Trust)

At the local level in Sheffield and Manchester, working in partnership with Children's Centres to deliver health promotion activities and programmes is an effective means of helping PCTs in both Sheffield and Manchester to meet public health priorities such as reducing health inequalities, reducing adult smoking rates, or halting the rise in obesity among children (DoH, 2007).

Both Sheffield and Manchester experienced a major re-organisational transformation in PCTs that influenced the implementation process of Sure Start policy at the local level. The number of PCTs in England was reduced from 303 to 152 on 1 October 2006 in order to create a closer relationship between health, social care and emergency services, improve value and services for patients, develop better emergency planning with more resources to respond to major incidents and ensure that service continued as normal, with more money for frontline services (DoH, 2008).

In Sheffield, PCTs have been merged from the original four PCTs to one PCT that currently manages three Sure Start Children's Centres. Since 2004, the PCT also is no longer accountable for delivery and the local authority is accountable in Sheffield. Given that the PCT was the accountable body under the original Sure Start Local Programme, it has been quite difficult for the PCT to shift from having autonomy around how the partnership can make decisions and develop services to actually having to work within a specifically scheduled framework. 'It is quite difficult to move from where the PCT had power and control over the process to being in a position where you are actually not leading and controlling delivery, which is now done by the EYECS' (Personal interview). In addition, one of the senior officials from Sheffield local authority argued that:

We haven't particularly had one here, they have their own monitoring and recording, we have our own monitoring and recording. They are not same thing, and we are not allowed to access to the PCT data 
under NHS and it is restricted. They don't want to do our data, because they have done once for the PCT, and it is not that you have problems with monitoring and recording, because you are not allowed to access PCT data.

In Manchester, the PCT has also undergone major reorganisations in 2007. There were three different PCTs in north, central and south Manchester under the Sure Start Local Programmes but now they have been merged into one PCT. The organisational transformation of the PCT has brought a series of problems in implementing Sure Start policy in Manchester. One of the officials from Manchester local authority said that

When we have local programme, we work with three different PCTs, in north, central, and south PCTS, and last year, they became one PCT. They had a major re-organisation, and brought a big problem, you know in terms of how different personnel, different managers do the different parts of the work. That has brought us a few problems.

In addition, based on the interview materials in Manchester, the PCT re-organisation has caused difficulties for the Sure Start Unit to engage with them in delivering health services in Sure Start Children's Centres, because PCT's capacities have been too stretched to meet their needs. One of the managers in Sure Start Children's Centres argues 'there have been less contributions from PCTs since they had a major reorganisations' (Personal interview).

\subsubsection{Issue Network and Its Impact on Sure Start Delivery}

Under the context of 'multi-agency' work, there are a large number of voluntary, independent and private partners involved in Sure Start policy, and these actors vary in different areas. However there are some key actors responsible for running the Sure Start Children's Centres, such as NCH and MCDT in Sheffield, and the Big Life Company and Barnardo's in Manchester (See Figure 4).

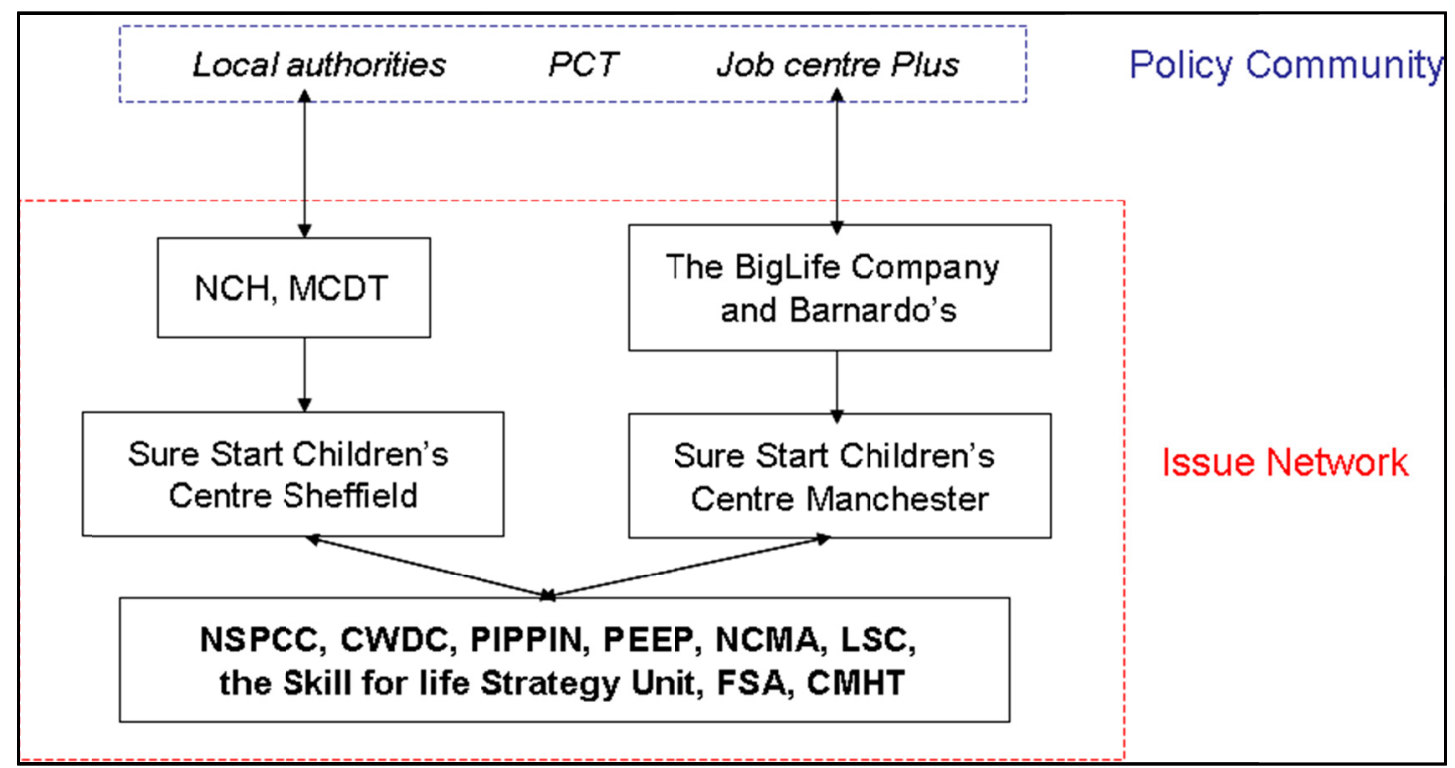

Figure 4. Issue network in Sheffield and Manchester

Based on interviews in both Sheffield and Manchester, it is agreed that Sure Start Children' Centre is one of the few stable actors in the issue network and acts as a role linking different services in the Children's Centres. One of the managers from the Centre in Manchester commented:

In a way, children' centre provide a glue for some of the activities already happening. There is a lot more community cohesion than before, because centre give us a opportunity to do this, and in fact, a lot people have said it to me. Not just my assumption. Centres are providing coordination to a lot of activities.

One of the managers from Sure Start Children's Centres in Sheffield also said that 'everybody in the building, because it is the contact point with health visitors, park rangers, everybody using in the building, that is the cost we bear alone'.

As illustrated above, NCH and MCDT in Sheffield and the BigLife Company and Barnardo's in Manchester are main actors in the issue network, which are partly responsible for delivering Sure Start Children's Centres. 
Furthermore, in both Sheffield and Manchester, there are a large number of voluntary, independent and private actors coming in and out of the issue network. There is a very limited stability and continuity in the Sure Start issue network (see figure 4). One of the managers from the Sure Start children's centre in Sheffield commented:

In terms of provision here, we have local authority provisions, parenting in course in Sure Start Children's Centres, and we have a close link with primary schools, and work with NSPCC, it is not proactive in our areas, but they are active in other areas.

Based on the interviews, it can be seen that in terms of service provision, different Children's Centres in both Sheffield and Manchester employ different providers, such as day care services. One of the managers from Sure Start Children's Centres in Sheffield commented that 'at the moment, you are right; there are a lot of people from different backgrounds (voluntary, independent and private actors) and we are working together'. In Manchester one of the managers from Sure Start Children's Centres commented:

Yes, more or less, if there isn't Sure Start centre its own right, it will be a satellite for Children Centre somewhere. So my colleague works in Ashburn Meadow, she is attached to a school, her satellite deliver her day care, it is called Hibry Close, it is a separate building, that does the day care. They are all different. Saindland Children Centre have a private company providing the daycares, it is a private provider from the area.

In addition, actors in the issue networks in both cities all have their own different resources enabling them to be involved in the implementation process. For example, some Children's Centres in Sheffield need to use the premises of primary schools, or need staff from some voluntary organisations. In Manchester one of the managers from Children's Centres commented that:

We are working with extended school team, because their agenda is very similar with the Sure Start agenda, and on the ground we also are working closely with local primary school and in fact this centre will move in with newly built primary schools.

However, there is a similarity in both Sheffield and Manchester in that actors in the issue networks don't share the same goals with each other, resulting in the 'network structure' being loose. For example, in both Sheffield and Manchester, Childminders provides childcare services for the Children's Centres; however, they have their own network team from the National Childminder Association and only come to the Centres once a week. Furthermore, the relationship between actors in the issue network is at times consultative. For example, the Citizen's Advice Bureaus manage through a consultation process, which is in the voluntary community sector. One of the managers from Sure Start Children's Centres in Sheffield illustrated that:

We have a partnership board with members of community, parents, local businessman, Sure Start, other local projects, actually oversee what we do and they had the main sort of say on whether buildings is in a particular way, what we deliver from that building, it came through what is called local partnership board, they had pack of what we deliver at that.

In addition, actors in the issue networks in both Sheffield and Manchester also intend to provide services without significant resource exchange. However, under some circumstances resource exchange does take place to enhance the overall capabilities of meeting the needs of actors in issue networks. One of the managers from a Children Centre in Manchester illustrated:

Local authority definitely, and within it, like area planning coordinator, keep abreast with them, the two local forum, they already deliver a lot of services. They've got community view, one of the difficulties for us to face is the funding for phase 1, it isn't there for us, we cannot buy in service, we've got to link what services are already there by other providers. Local players and partners are critical.

Financially, Sure Start Children's Centres in both Sheffield and Manchester don't have enough funding to develop all the services and some of managers are part of a local group - a public health involvement team - and they manage to draw down some funding (e.g. from PCTs), which is used alongside to develop services. Furthermore, sometimes partnerships are not well coordinated. One of the managers from the Sure Start Children's Centres in Sheffield argued that 'We have to make sure what they are doing is coordinated in the way that makes sense to children and families, and they know who is delivering services, how to access, so if we do not work with key partners, we are not providing accessible equitable service to people' (Personal Interview). Another of the managers from the Sure Start Children's Centres in Sheffield also argued:

The headache I suppose is that we have number of agencies based in the building. The headaches is really who pays what to keep the building, what budget pay for what; for example, we pay for the reception staff, which are used by health visitors, park rangers, everybody in the building, because it is 
the contact point with health visitors, park rangers, everybody using in the building, that is the cost we bear alone, that is quite complicated arrangement about square footage and the building, funded after one budget after another.

Finally, in the Sure Start issue networks in both Sheffield and Manchester there is not a highly integrated structure. The structural arrangement is not well-organised, which leads to the duplication of resources affecting the implementation process. One of the managers from the Sure Start Children's Centre in Manchester illustrated:

Probably the baby group might be one of them, in the health visitors very involved in with children under five, very interested in running community clinic, and post-natal groups, that overlaps part of what we might do. We have looked at with health visitors in how we might duplicate services. So they might run the post-natal group from mums, at the same time, we might run something called baby group, which is quite similar in as much as much with children under twelve months come along with groups to meet other mums. We have been looking at this.

\section{Street-level Bureaucrats' Autonomy in Delivering Sure Start}

There is a substantial literature on the autonomy of street-level bureaucrats and its influence on the policy outcomes. Jacobs (1970) and Zimmerman (1969), both taking a phenomenological approach, have pointed out the independence and influence of caseworkers in public welfare agencies. Handler and Hollingsworth (1971) use a more policy-oriented approach and come to substantially similar conclusions. Certain characteristics of the jobs of street-level bureaucrats make it difficult to severely reduce discretion and autonomy. They undertake complex tasks for which elaboration of rules, guidelines, or 'instructions' cannot circumscribe the alternatives of implementing tasks. Through the interviews, it is shown that street-level workers in Sure Start from both Sheffield and Manchester all have relative discretion and autonomy.

\subsection{Street-Level Bureaucrats as Decision-Makers in Sure Start}

The decisions made by street-level workers, the routines established by them and the devices they invent to cope with uncertainties and work pressures effectively become the public policies they carry out (Lipsky, 1980). As implementation network approach suggested, Decisions in public policy are not merely made in legislatures or by high-ranking governmental officers, because in important ways they are actually made through street-level workers at the grass-roots.

Street-level bureaucrats in both Sheffield and Manchester also agree that they sometimes work in situations which are too complicated to predict, and at most times, it is extremely difficult to work in the programmatic formats set by their superiors. Abstract situations are fluid and need discretion to reduce broad public problems into something less ephemeral and more manageable for a public service worker (Wong, 2007). Bovens and Zouridis agree that decision-making power helps street-level bureaucrats to constrain broad administrative procedures into concrete situations (Bovens \& Zouridis, 2002).

In both Sheffield and Manchester, street-level bureaucrats encounter circumstances of working in diverse communities, which increases the uncertainties of delivering Sure Start services to local clients. Hence, the decision-making power of street-level bureaucrats can help them reduce the difficulties of implementation to a manageable level. One of the managers from Sure Start Children's Centres in Manchester argued that:

In this community, it is such a diverse community, and culturally diverse community. People move in and out very quickly. We're still not working in a joined-up with all agencies, although we are a lot better than we were, we still got a long way to improve that. I don't think we are equipped to meet needs of the best way for all families, that is hard and there is typically culture barriers as well, then you got language barriers on top of that.

One of the managers from Sure Start Children' Centres in Sheffield commented that 'we are working in a highly diverse community with lots of ethnicity, and we do allow our family outreach workers to make their decisions regarding dealing with different cultural needs in this community' (Personal interview).

Street-level bureaucrats in both Sheffield and Manchester also have the responsibility and autonomy to decide which direction they intend to take. As Yvonne argues, in response to managing workloads and addressing the needs of clients, there is certain urgency for street-level bureaucrats in making judgments and executing decisions (Yvonne, 2000). Staff interviewed in Sure Start Children's Centres in Sheffield and Manchester illustrated that they have the power to decide in which direction they give support to the family in need, what kind of support they require and how much support they give them (personal interviews). 
The implementation network approach recognises the intricacy of membership in the network, but also argues that street-level bureaucrats' discretion and autonomy influences the partnerships among organisations involved in the implementation process. In terms of partnerships, managers in Sure Start Children's Centres have the initiative to include or exclude partners in order to reach the objectives of Sure Start policy, which is also a common characteristic in Sheffield and Manchester. For example, Sure Start Children's Centres encounter difficulties in collaborating with Jobcentre Plus in both Sheffield and Manchester. In dealing with this difficulty, different strategies are employed in both Sheffield and Manchester. In Manchester, managers tend to be more inventive in bringing in other partners from voluntary, independent and private sectors. One of the managers from Sure Start Children's Centres in Manchester illustrated that 'we have to be quite inventive. For example, we don't have a good relation with Jobcentre Plus. However, we can bring other partners into delivering worklessness agenda; something I was talking with you about, then you just find different way of doing that' (personal interview). On the contrary, in Sheffield, managers tend to take measures to attempt to build closer connections with Jobcentre Plus at the local level. One of the managers from Sure Start Children's Centres in Sheffield commented that 'we try to make more connections with Jobcentre Plus to solve the problems we face, such as lack of staff in the Centre' (personal interview).

Finally, there is a similarity that street-level bureaucrats interviewees in both Sheffield and Manchester argued that targets could also be a source of tension for street-level bureaucrats, because they were often seen as not the right ones and not realistic or blurry, at least for a particular agency involved in the Sure Start policy. In Sheffield, interviewees in Sure Start Children's Centres express their concerns on some targets without figures, such as reduction in the number of smoking mothers during pregnancy and improving the access of early years provision for children with special education needs and disabilities. These targets trigger tensions for street-level workers and are seen as unclear and inappropriate by interviewees. In Manchester, interviewees in Sure Start Children's Centres also show concerns over unclear and unrealistic targets, such as reducing smoking in pregnancy, reducing low birth weight and improving diet and nutrition. One of the interviewees in Sure Start Children's Centres in Manchester commented that 'there are some targets that are difficult to measure and execute' (Personal interview). Prottas argues that 'ambiguity and contradiction are basic features in the organisation's expectations of street-level bureaucrat behaviour' (Prottas, 1978: 295).

\subsection{Street-level Bureaucrats as Implementers in Sure Start}

Street-level bureaucrats influence the implementation process of Sure Start policy not only as decision-makers, but more importantly act as implementers and determine how Sure Start policy made in the decision stage is translated on the ground. There is a similarity in both Sheffield and Manchester in that a lack of resources has become an inexorable factor influencing the behaviour of street-level workers as implementers. One of the workers in Sheffield commented that 'we are very constrained by the fact that you have very limited resources which is the key factor. So your ability to do anything is limited because you don't have any resources to spend' (personal interview). One of the street-level bureaucrats in Manchester also commented that a 'shortage of staff and money has been a big constraint for us to provide the services to the people in this community' (personal interview). According to Lipsky (1971) and Prottas (1978), street-level bureaucrats always work with inadequate resources in circumstances where the demand will always increase to meet the supply of services, as shown above in both Sheffield and Manchester. Thus they can never be free from significant constraints.

The implementation network approach recognises that street-level bureaucrat exercises controls on the existing and potential service users by distributing benefits and sanctions, instructing clients on how to behave or using their own routines. Based on the interviews from Sheffield and Manchester, it can be seen that street-level workers in Sure Start often face the constraints of time and resources in delivering services to clients, and they intend to take various means to ration services in both cities.

Goffman argues that 'the business of public service bureaucracies is to categorise clients, to provide service to a citizen a bureaucracy must first reduce that citizen and his or her demands into a simple and patterned package of processable attributes' (Goffman, 1973: 79-109). a report 'Jobcentre Plus and Children's Centres' from DWP argued: 'The simple pressures on time and responsibilities which staff in a range of organisations experience can also mitigate against partnership working on a more day-to-day basis and it is at this level that relationships can become more fully established' (Dench, Aston, James, \& Foster, 2008: 78). in Manchester one of the street-level workers commented that 'we have a lot of families to support, and due to the time constraints, we sometimes have to signpost them to other organisations, or tell them that they would have to wait for us and we will be not going to be able to meet their needs right now' (personal interview). Furthermore, street-level workers in Sheffield also show their concerns on the time pressure of linking with different key partners. 
Street-level bureaucrats in both Sheffield and Manchester have all experienced difficulties working with PCTs and Jobcentre Plus, but in different forms. In Sheffield, a lack of trust and respect among street-level bureaucrats influences the good partnership between street-level bureaucrats. The existence of trust is crucial to the task of information sharing, as is reaching out to the objectives shared by different agencies or organisations. One of the street-level bureaucrats in Sheffield expressed the distrust or lack of confidence with health visitors or midwifery and commented:

I think you just don't know what their job is, and you have to find out what they do in order to say you can come to our place and do your things. If you don't know what actually their role is, what kind of thing they can do in our community and how they go to work when a baby is just born. And sometimes I am just not confident in them because I find out that they are not highly committed to the jobs we have here in the centre, and seem to me they have got loads of work to do in their own department.

Finally, the implementation network approach also highlights the autonomy of street-level bureaucrats as implementers in coping with targets. As implementers, they also have to face insufficient resources to reach unclear or unrealistic targets and conflicting targets. For example, one of the lower-level workers in Manchester commented that 'in terms of number of reducing the child poverty by 2010 , you get data, but in terms of other figures, I just don't know whether they would be good or bad thing. Sometimes, they would say you have failed if you don't achieve those figures. Performance management has always been an issue throughout this policy' (personal interview). In Manchester, in the more ethnically diversified areas, Children's Centres also have to employ interpreters to accompany health visitors, midwives and parental support workers. However, based on the interviews, lack of funding, such as a shortage of funding for interpreting services, has put a constraint on street-level bureaucrats in meeting their objectives of reaching out to the most needed families, including minority groups.

\section{Conclusion}

Sure Start has been one of the flagship policies under the New Labour government, and Sure Start Children's Centres have been the vehicle for reducing the gap in outcomes between disadvantaged children under five and the wider child population. This paper attempts to analyses the implementation process of Sure Start under the context of Labour's commitment to improving public service delivery through the implementation network approach. In the first place, as the interviews revealed, it can be seen that some frontline staff in both Sheffield and Manchester has experienced the benefits of more autonomy and discretion in dealing with local issues.

However, compared to the power of the central government, the relationship between the centre and non-state actors is still largely asymmetric, and the central government has employed a variety of indirect measures to control the behaviour of frontline staff. Interviews of street-level workers in both Sheffield and Manchester show that their behaviour is considerably restrained by targets and limited budgets and resources, which are largely controlled by the central government. Secondly, there are two types of policy networks in Sure Start policy. Policy community and issue network co-existed in implementing Sure Start policy. Within the policy community, the paper analysed their ideological and institutional divisions and how these differences impact on the implementation process of Sure Start. In addition, the paper also analyses how the voluntary and private actors involved in the implementation process through issue network. Finally, for policy makers, micro-level analysis provides a basic understanding of human behaviour that helps to guide the selection of a governance strategy. Based on the interviews undertaken for this research in both Sheffield and Manchester, it can be seen that street-level bureaucrats play an important part in the implementation process of Sure Start.

\section{Acknowledgements}

This paper was supported by Beijing Normal University Independent Research Funds (Grant \#2012LYB15).

\section{References}

Barber, M. (2007). Instruction to Delivery: Tony Blair, Public Services and the Challenge of Achieving Targets. London: Politico's Publishing.

Blair, T. (2001). Prime Minister's Speech on Public Service Reform. London: Downing Street Press Office. Retrieved May 20, 2007, from http://www.number10.gov.uk/Page1632

Bovens, M., \& Zouridis, S. (2002). From Street-Level to System-Level Bureaucracies: How Information and Communication Technology is Transforming Administrative Discretion and Constitutional Control. Public Administration Review, 62(2), 174-185. http://dx.doi.org/10.1111/0033-3352.00168

Boyne, G. A. (2003). What is Public Service Improvement. Public Administration, 81(2), 211-227. 
http://dx.doi.org/10.1111/1467-9299.00343

Cabinet Office. (2003a). Leading from the Front Line: The Prime Minister's Office of Public Service Reform. Retrieved from http://archive.cabinetoffice.gov.uk/opsr/documents/pdf/leadopsr.pdf

Cairney, P. (1999). The Network-Actor Approach to Policy Networks. PhD thesis.

CommunityCare.co.uk. (2005). Sure Start Founder Attacks DoH's Indifference. Retrieved from http://www. communitycare.co.uk/Articles/2005/06/07/101211/sure-start-founder-attacks-dohs-indifference.html.

Dench, S., Aston. J., James, L., \& Foster. (2008). Jobcentre Plus and Children's Centres, A Report of Research Carried out by the Institute for Employment Studies on behalf of the Department for Work \& Pensions. Retrieved from http://www.dwp.gov.uk/asd/asd5/rports2007-2008/rrep485.pdf

Department of Health. (2007). Delivering Health Services through Sure Start Children's Centres. Retrieved June, 2007, from http://www.dh.gov.uk/en/Publicationsandstatistics/Publications/PublicationsPolicyAndGuidanc e/DH_076333

DoH. (2008). Reorganisation of Ambulance Trusts, SHAs and PCTS. Retrieved from http://www.dh.gov.uk/en/Managingyourorganisation/Healthreform/DH_4135663

Foley, M. (2000). The Blair Presidency. Manchester: Manchester University Press.

Goffman, E. (1976). Asylum, Garden City. New York, Anchor Books.

Guardian. (2005, December 1). Sure Start Sets Back the Worst Placed Youngsters, Study Finds. Retrieved May 30, 2007, from http://www.guardian.co.uk/society/2005/dec/01/childrensservices.c hildprotection

Hajer, M. (2003). Policy without polity? Policy analysis and the institutional void. Policy Sciences, 36(2), 175-195. http://dx.doi.org/10.1111/1467-9299.00343

Handler, J. F., \& Hollingsworth, E. J. (1971). The Deserving Poor. Chicago Markham.

Hay, C. (2002). Political Analysis. Basingstoke Palgrave.

Hill, D. (1974). The Art of Muddling Through: Policy-Making and Implementation in the Field of Welfare. Madison: University of Wisconsin Press.

Hill, M., \& Hupe, P. (2002). Implementing Public Policy. London: Sage.

Hjern, B. (1982). Implementation Research - the Link Gone Missing. Journal of Public Policy, 2(3), 301-308. http://dx.doi.org/10.1017/S0143814X00001975

Hjern, B., \& Porter, D. (1981). Implementation Structures: A New Unit of Administrative Analysis. Organizational Studies, 2, 211-227. http://dx.doi.org/10.1177/017084068100200301

Hyndman, N., \& Eden, R. (2002). Executive Agencies, Performance Targets and External Reporting. Public Money \& Management, 22(3), 17-24. http://dx.doi.org/10.1111/1467-9302.00314

Jacobs, G. (1970). Life in the Colonies: Welfare Workers and Clients. The Participant Observer: Encounters with Social Reality (pp. 240-260). New York: George Braziller.

James, O. (2004). The UK Core Executive's Use of Public Service Agreements as a Tool of Governance. Public Administration, 82(2), 397-419. http://dx.doi.org/10.1111/j.0033-3298.2004.00400.x

Lipsky, M. (1980). Street-level Bureaucracy: Dilemmas of The Individual in Public Services. Madison, University of Wisconsin Press.

Lowndes, V., \& Skelcher, C. (1998). The Dynamics of Multi-Organisational Partnerships: An Analysis of Changing Modes of Governance. Public Administration, 76(Summer), 313-333. http://dx.doi.org/10.1111/1467-9299.00103

Marsh, D., \& Smith, M. (2000). Understanding Policy Networks: Towards a Dialectical Approach. Political Studies, 48(1), 4-21. http://dx.doi.org/10.1111/1467-9248.00247

Needham, C. (2007). The Reform of Public Services under New Labour: Narratives of Consumerism. Basingstoke: Palgrave Macmillan. http://dx.doi.org/10.1057/9780230593169

Newman, J. (2001). Modernising Governance, New Labour, Policy and Society. London: Sage.

Office of Deputy Prime Minister. (2003). A Better Education for Children in Care: Social Exclusion Unit Report. Retrieved from http://www.cabinetoffice.gov.uk/media/cabinetoffice/social_exclusion_task_force/assets/ publications_1997_to_2006/abefcic_summary_2.pdf 
Office of Public Service Reform. (2002). Reforming Public Services: Principles into Practice March. London, Stationary Office.

Performance and Innovation Unit. (2000). Reaching out, the Role of the Central Government at Regional and Local Level. Retrieved from http://www.cabinetoffice.gov.uk/media/cabinetoffice/strategy/assets/reaching _out.pdf

Pressman, J., \& Wildavsky, A. (1973). Implementation. Berkeley, CA: University of California Press.

Prottas, J. M. (1978). The Power of the Street-Level Bureaucrat in Public Service Bureaucracies. Urban Affairs Review, 13, 285. http://dx.doi.org/10.1177/107808747801300302

Richards, D., \& Smith, M. (2005, April 1-2). Institutional Reform for Political Control: Analysing the British Labour Government's Approach to the Pathologies of Governance. A Scancor Workshop in Collaboratoin With SOG. Stanford University.

Sabatier, P. A., \& Jenkins-Smith, H. C. (1993). Policy Change and Learning, an Advocacy Coalition Approach. New York, Westview.

Smith, M. J., \& Ludlam, S. (2004). Governing as New Labour. New York, Palgrave Macmillan.

The Secretary of State for Social Security. (1999, September). Opportunity for All, Tackling Poverty and Social Exclusion. First Annual Report.

Times. (2007). Blind Feminism has Hurt Our Children, Sure Start is Typical of Labour's Failure. Retrieved October 15, 2009, from http://www.timesonline.co.uk/tol/comment/columnists/guest_contributors/article 1386943.ece

Whitfield, D. (2006). New Labour's Attack on Public Services. Spokesman, Nottingham.

Wong, W. (2007, October 16). Street-Level Bureaucracy: Dilemmas of the Individual in Public Services. Politics of Policy Making and Implementation.

Yvonne, O. B. (2000). Implementing Policies within an Institutional Framework. School of Politics and Public Policy, Griffith University. PhD dissertation.

\section{Copyrights}

Copyright for this article is retained by the author(s), with first publication rights granted to the journal.

This is an open-access article distributed under the terms and conditions of the Creative Commons Attribution license (http://creativecommons.org/licenses/by/3.0/). 